\title{
INTENSIFICATION OF HEAT AND MASS TRANSFER AND DEWATERING OF THERMOLABILE ORGANIC MATERIALS
}

\author{
Liashenko A., Candidate of Engineering Sciences, senior research scientist \\ Institute of Engineering Thermophysics of the National Academy of Sciences of Ukraine, Kyiv
}

Ukraine has a high level of industry, agriculture and consumption. As a result of underutilization of recovered materials and their products into the environment returns significant amount of waste that contaminate soil, water, air. Dumps occupy large areas, long ground beneath them put out of production, they pollute the environment. The main causes of waste, lack of effective processes and capacities of processing residues, spatial and chronological dissociation processes of waste and their use, lack of sufficient market.

Of all the organic waste in Ukraine is one of the main places belong chicken droppings. Fresh droppings quickly oxidizes the soil, humus and inhibits microorganisms, disrupting its natural ecosystem biological community. With some preparation and processing of chicken manure is a high quality fertilizer that contains chemical elements $(N, P, K)$, macro- and micronutrients, humic acid and other components that are essential for growth and fertility of different plants.

For decontamination litter widely used thermal drying at $t=600-800{ }^{\circ} \mathrm{C}$. This product is well kept dry, easily transported, but using traditional drying facilities for its handling used large amount of heat.

Today continually created and offered new modern technologies for processing chicken manure.

At the Institute of Engineering Thermophysics NAS of Ukraine many years conducted investigations on the creation of modern technologies and equipment for processing organic waste.

Analysis of the traditional intensification methods and processes of heat and mass transfer during drying of materials was presented in the paper. The author has proved the promising nature of the method of the combined processes of drying and dispersion using a mechanical rotor to intensify the process of drying of high-moisture thermolabile materials.

Keywords: biomass, energy efficiency, resource conservation, technology, equipment.

\section{Introduction}

It is now known that drying is a complex technical and technological process that may depend on a large number of known and unknown factors. These factors need to be known for analysis, calculation and influence on the drying process.

The intensity of the drying process depends (or is determined) by the speed of the drying process. When approaching the equilibrium state usually decreases and tends to zero. There are a number of factors that affect the intensity of the drying process, which indicates the real complexity of the drying process and obtaining a mathematical description for it. This applies separately to production conditions. One of the main factors influencing the drying process is the factors that define the material as the object of the drying process. They always characterize the resistance of the material itself to the transfer of moisture, both inside and from its surface to the environment, as well as the strength of the connection of moisture with the material, the ability of the material to absorb heat supplied to it. These factors include the internal structure of the material, its size, thermophysical properties, the time of change of moisture content of the material during drying, the shape and condition of the outer surface [1]. It is important to find ways to intensify the process of heat and mass transfer in the drying process of various materials in practice.

The following traditional methods of intensification of the drying process in the working volume of technological equipment are known, which are as follows: the possibility of intensification of the heat and mass transfer process at the interface of the phases; development of the working surface of the contact phases; increasing the speed of the coolant; by reducing the linear size of the material; by increasing the value of temperature pressure.

It is possible to use different conditions that allow to create artificial turbulence of the flow, if it is technologically acceptable and possible. When drying materials use the effect of artificial turbulence of the coolant flow. It can be obtained by giving the surface of products of different (rational) waviness and / or roughness. This allows to increase the heat transfer coefficient by $45-95 \%$ and increase the heat and mass transfer surface [2].

Known vibration methods of flow turbulence. In some types of dryers, studies have shown that they have intensified the heat transfer process. Heat exchange surfaces during vibration in the liquid increase the heat transfer coefficient by 1.5 - 2 times, while in the air in 1.5 - 4 times [3].

Of great interest from a practical point of view are the vibrations of the materials to be dried, especially those of small size. Such vibration can be carried out mechanically in the layer of fibers during drying of the dispersed 
moving material and others. Particles of material that have received an electrostatic charge during dispersion or otherwise can also be subjected to vibration in the coolant stream by applying pulsating electric fields.

Intensification of moisture transfer in the middle of the material during drying is very important. It is an interconnected set of processes. This complex consists of the following processes: violation of the connection of moisture with the material; diffusion of moisture through its elements; movement of moisture through capillaries; transfer of steam and gas phases; excitation and formation of polymolecular films; electrostatic connections of moisture with the material and other processes. As a rule, the smaller the size of the material to be dried, the more intense the processes of internal transfer.

The existence of concentration fields has a significant effect on the transfer of moisture in the material, temperature fields and the direction of heat fluxes. When transferring moisture in the material, the main driving force is the concentration gradient.

Thermodiffusion can interfere with or promote moisture transfer. In this regard, the supply of heat in the direction of moisture movement, which is carried out by contact, is promising. The current is conducted through the material or elements that conduct it in it, as well as the possible use of high-frequency and induction heating.

Numerous studies show that the drying process is significantly accelerated by increasing the temperature of the material from 45 to $95{ }^{\circ} \mathrm{C}$. This is due to changes in the viscosity of moisture in the material and the violation of polymolecular films. Of scientific interest are data on the influence of acoustic oscillations of the coolant flow on the process of moisture transfer in the material. This is due to the pulsation of pressure on the surface of the material, which helps to remove moisture from it.

We know from theory that the drying process begins with the formation of a pressure difference above the surface of the material and in the surrounding environment at a temperature difference that provides heat supply, which leads to a change in the physical state of moisture.

A wet body is heated by the supply of heat, and its temperature increases to a value called the temperature of the wet bulb thermometer. Its value depends primarily on the temperature and partial vapor pressure in the surrounding environment. For some time, this temperature remains constant as long as evaporation occurs from the surface of the body, and is not limited by the intensity of the supply of moisture from the deep layers. The rate of moisture removal from the material depends only on the conditions of heat supply to it and the removal of vapors from its surface. During this period, the drying rate is determined only by the rate of heat supply to the material and at a stable mode is constant.

The supply of heat from the deep layers of the material to its surface during this period does not affect the drying process. The period in which the constant temperature of the material and the rate of moisture removal is called - the first period.

Since the speed of the drying process increases while maintaining a safe temperature of the material, in terms of its quality, it is safe to intensify any drying process by supplying heat.

As moisture is removed from the surface layers of the material, the drying process begins to be limited by reducing the rate of moisture supply from the deep layers to the evaporation surface. In the first stage, the evaporation process continues from the surface of the material with a gradual decrease in process speed and increase in material temperature.

In the second stage, the intensity of the movement of moisture decreases, the evaporation zone moves from the surface to the depth of the material with a sharp increase in temperature on its surface. The second period of drying comes. There is a more intense increase in the temperature of the surface layers of the material. Moisture removal is significantly reduced, and most importantly, there is over dried surface layers of material with high temperature. Violation of the connection of moisture with the material and its transfer and determine the speed of this drying period. To speed up the drying process, they must be intensified.

To overcome the thermal and diffusion resistance of materials, there are a number of ways to intensify the drying process in the second period. Here are some examples: drying with high frequency currents, creating an oscillating drying mode and drying with pressure relief.

The above methods of intensification can be partially implemented in the chambers of compatible processes. Under which is understood the complex thermal, mechanical, aerodynamic impact on the material, which leads to a decrease in internal and external resistance to the processes of mass and energy transfer, the amount of motion, while also increasing its integral characteristics. Integral characteristics of the process are the values of volumetric moisture and heat stress.

In practice, the chambers of compatible processes are narrowly specialized designs. Their choice is dictated by the physical, mechanical and structural features of the materials being processed.

Chambers of compatible processes can be classified and divided into the following groups according to the method of their implementation:

- drying and grinding;

- mechanical dehydration and drying;

- drying and granulation (suspensions, melts, solutions, powders);

- heat treatment and drying;

- drying with simultaneous chemical reactions;

Наукові праці, Том 85, випуск 1 
- drying with capture and formation of capsules.

As an example, we will give multifunctional devices with a controlled system of hydrodynamics, which are called devices with counter-rounded flows. They are designed for drying and simultaneous dust collection, heat treatment and drying, granulation and dehydration. Of practical interest is also the possibility of the following processes of chemical technology: desorption, conditioning, absorption.

When processing high-moisture thermolabile materials (chicken manure, various organic sludges, sludges after fermentation processes, etc.) it is most expedient to use a mechanical rotor located along the axis of the chamber when implementing the active hydrodynamic mode in the apparatus. This design of the device leads to the creation of a suspended layer of material, twisting of the gas flow of the coolant, reducing the adhesion of the material to the inner surfaces of the chamber, the constant renewal of the heat and mass transfer surface of the material.

From the analysis of the review of recent publications and studies, it follows that these installations are promising for intensifying the process of heat and mass transfer when drying thermolabile pasty materials. Atritor, Niro Atomizer and others are engaged in the production of such installations. The cost of their equipment for domestic enterprises is quite high. Unresolved issues are related to the organization of a stable operating mode when obtaining the final product in the form of granules, the absence of methods for calculating apparatus in publications [4].

Due to the strong adhesion properties of raw materials, at the initial section in the chamber of the combined processes, the walls can stick, which entails an increase in energy consumption for the rotor drive. Due to the insufficient efficiency of the dry-type dust collecting devices in combined process installations, the loss of finely dispersed dusty material with entrainment is possible, which is an extremely undesirable phenomenon. These technological difficulties are tied to the nature of the materials to be processed. Each of them requires an individual approach and study.

\section{Discussions of investigation}

The area of experimental research that is of practical interest to the author is marked in gray in Fig. 1. This area is in the range from $1 \mathrm{~mm}$ to $3 \mathrm{~mm}$. It can be characterized by a high specific value of the contact surface of the solid and gaseous phases $\mathrm{f}$. The consumption of thermal energy per $1 \mathrm{~kg}$ of evaporated moisture is minimized. The consumption of electrical energy to create active aerodynamic motion in the chamber is also characterized by a small value. From the point of view of practice, the work in this interval is of interest in the organization of the removal of the solid phase from the chamber of compatible processes.

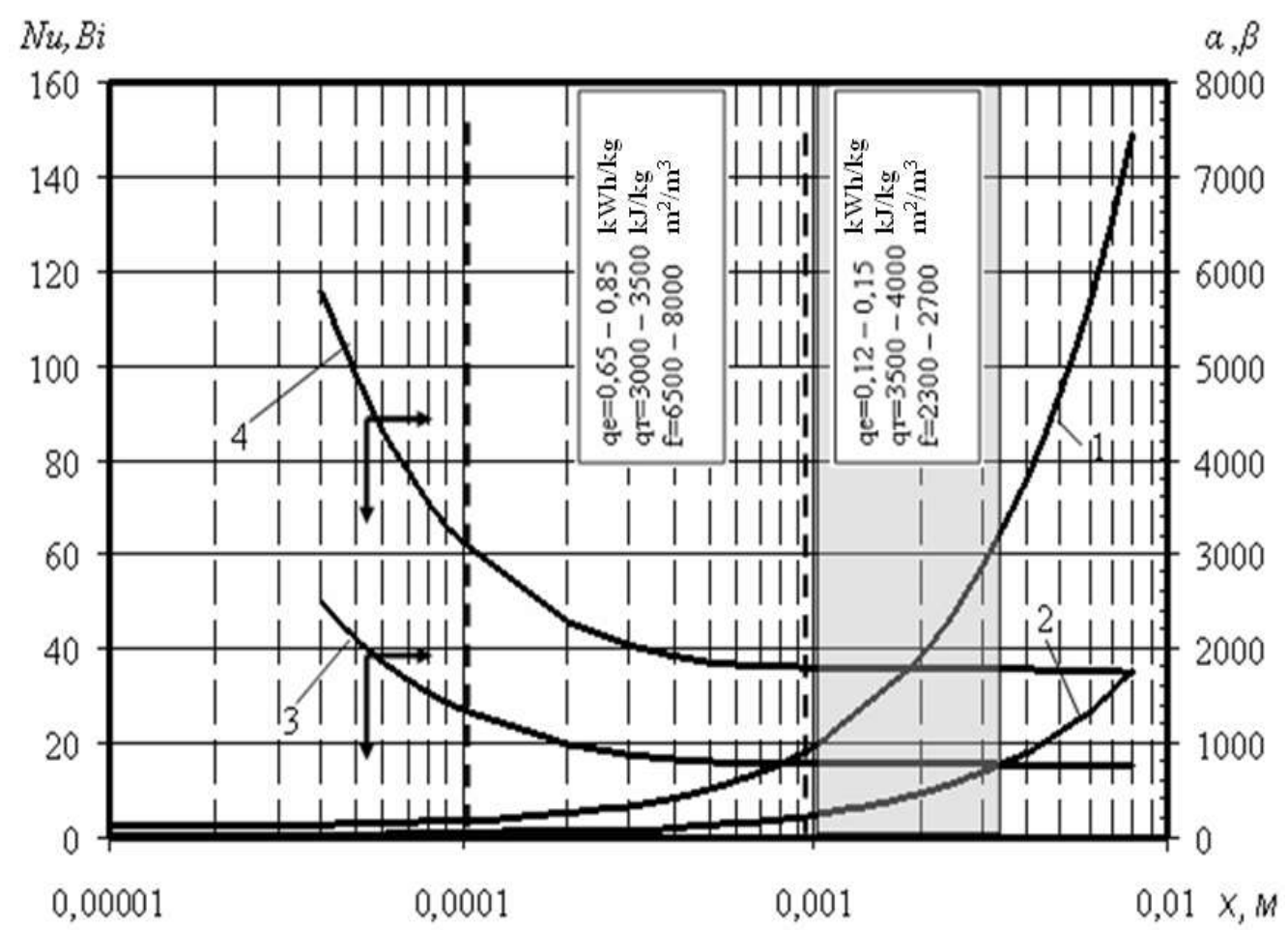

Fig. 1 - Influence of sizes of parts of material on size of criterion characteristics: 1 - Nusselt; 2 - Bio; 3 heat transfer coefficient $\alpha, \mathrm{W} /\left(\mathrm{m} 2 \cdot{ }^{\circ} \mathrm{C}\right) ; 4$ - mass transfer coefficient $\beta, \mathrm{kg} /(\mathrm{m} 2 \bullet \mathrm{hr} \bullet \mathrm{atm})$ 


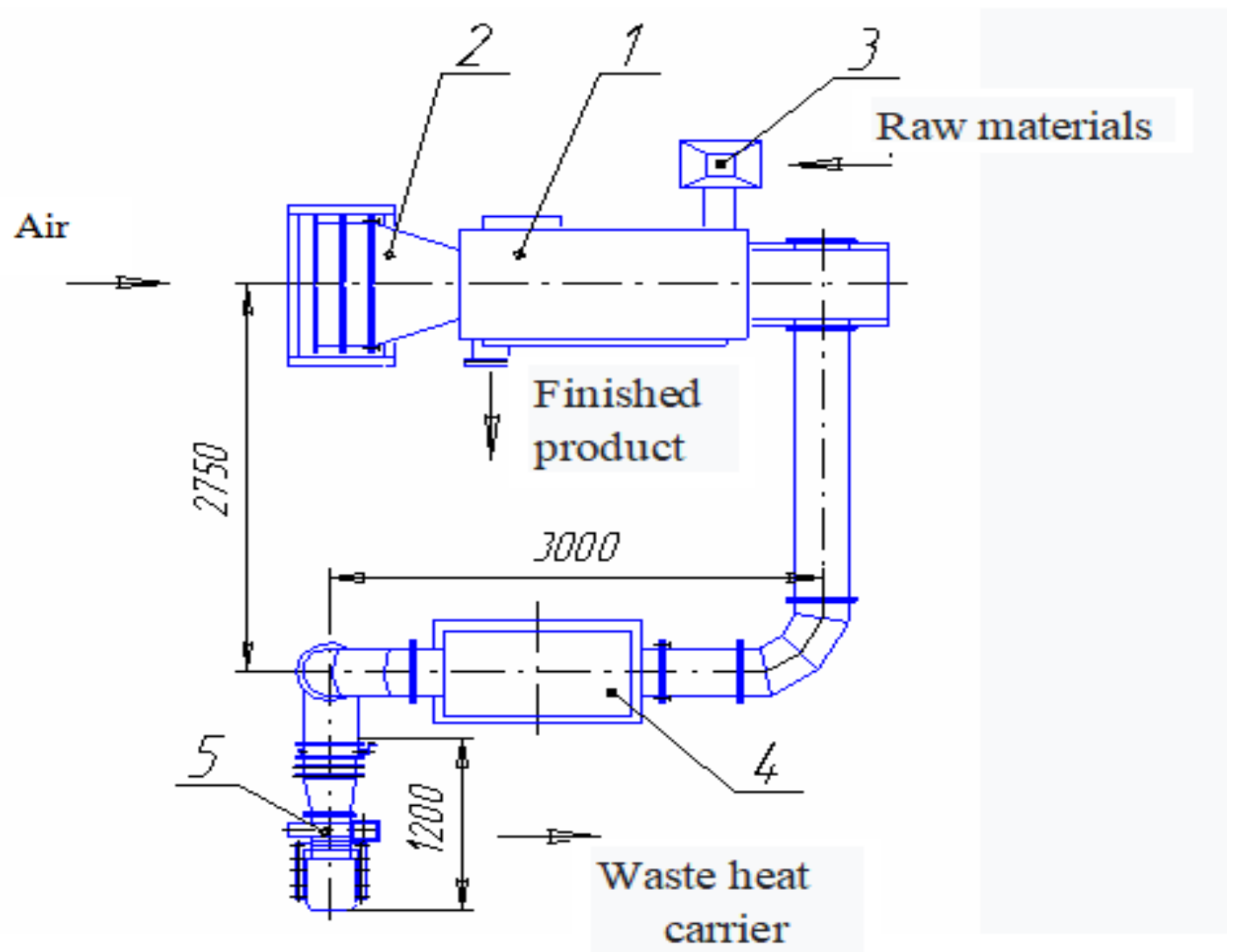

\section{1 - Chamber for combined grinding and drying (working chamber); 2 - Heat generator; 3 - Feeder; 4 - Dust separating device; 5 - Fan}

\section{Fig. 2 - The scheme of the installation for the combined process of drying and dispersion of thermolabile pasty materials}

The ITTF NAN of Ukraine has been conducting research on combined grinding and drying processes for a long time, as well as developing installations for heat treatment of finely dispersed labile materials $[5,6]$.

Research was carried out on drying and grinding green vegetation, clay, flesh, potatoes, bone meal, mucose, etc. Research showed the promise of using the drying method, the possibility of improving structures for various materials, and continuing research on the process of heat and mass transfer in them.

In recent years, a new design of the installation has been created at the ITTF NAN of Ukraine. In it, the disadvantages described above are largely eliminated or reduced.

The developed design provides the following operations: dosed feed of raw materials into the chamber of combined processes, joint grinding and drying of raw materials, implementation, if necessary, of an operating mode to obtain a dry product in granular form at the outlet of the installation.

The working chamber is a rotary device, which is a crusher-granulator of impact action, where the material is simultaneously subjected to mechanical and thermal effects. The design feature consists in dividing the working chamber of the installation along its length into zones and installing special mixing elements on the rotor (Fig. 2).

The installation allows you to process raw materials with almost any moisture content and obtain powders, both high dispersion and granules. In this case, the development of a large surface of heat and mass transfer occurs due to constant grinding and renewal of the heat and mass transfer surface. Overheating of the processed material is excluded. Loss of valuable nutrients is minimized. A short processing time leads to a decrease in the adhesive properties of the material (sticking). Full use of the temperature potential of the gas coolant in a small volume is ensured.

The installation (fig. 3) was tested on waste from a livestock farm. Raw material productivity reached $350-$ $400 \mathrm{~kg} / \mathrm{h}$ with a final moisture content of $12-14 \%$. The results obtained indicate the high efficiency of the installation. In separate specially set experiments, a stable operating mode was organized at the installation with the production of granules at the outlet. It is possible to obtain granules with a diameter of up to $6 \mathrm{~mm}$. 


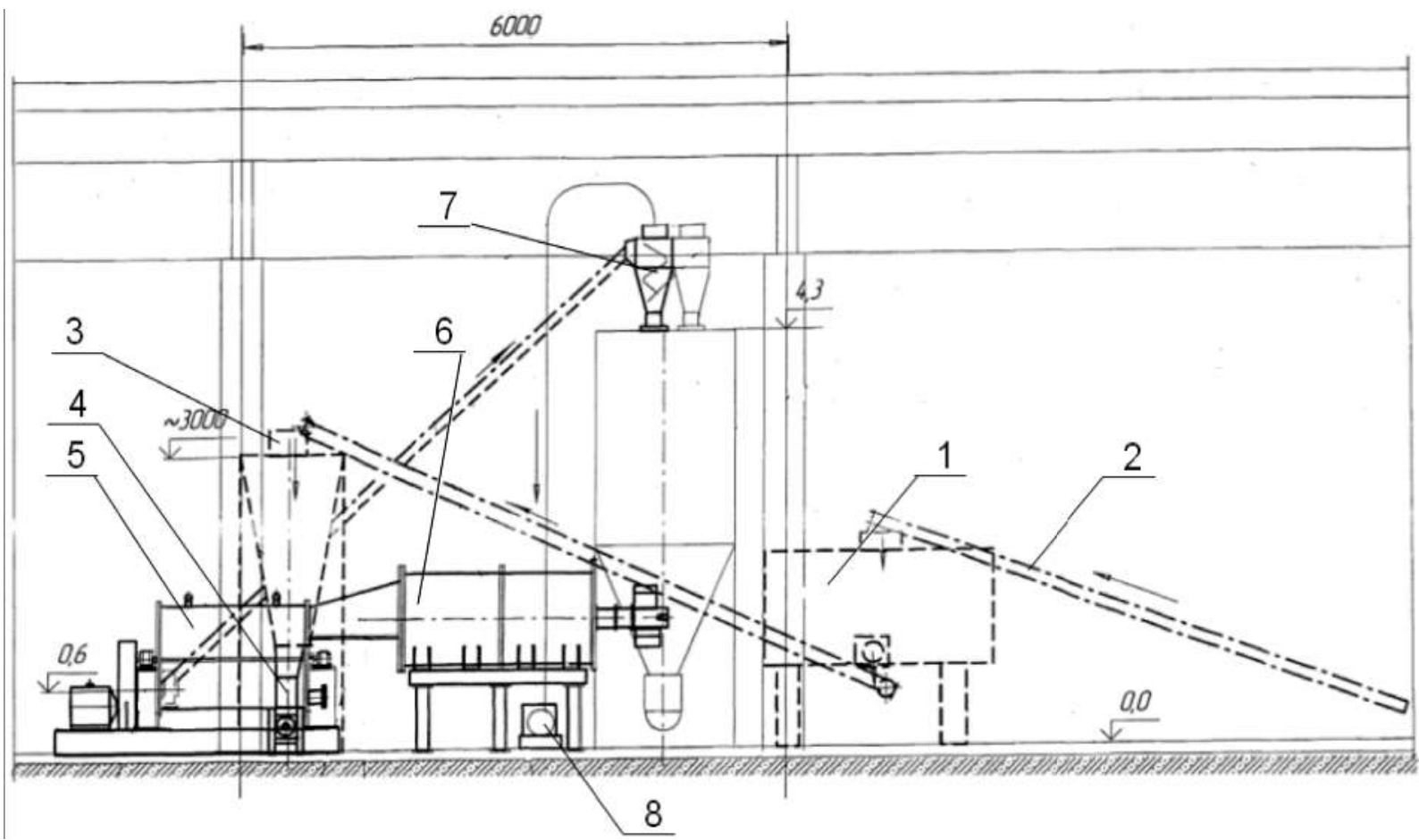

Fig. 3 - General view of the production of organic-mineral fertilizers based on chicken manure using the installation of compatible processes

The main components of the technological scheme (Fig. 3) are: 1 - auxiliary capacity; 2 - conveyor scraper RP - 500Sh - 40M; 3 - drive; 4 - feeder (ITTF equipment); 5 - dryer of compatible processes (ITTF equipment); 6 heat generator (ITTF equipment); 7 - group of cyclones; 8 - fan.

The introduction of the installation of compatible drying and grinding processes in the production plant of complex organic-mineral fertilizers at EKOTERRA LLC allowed to organize industrial continuous production with a capacity of $2300 \mathrm{t} /$ year of finished fertilizers, reducing energy costs for drying a unit of production by $20-30 \%$, reducing capital costs. construction and lease of premises for production.

With relatively low costs for optimization of production, the payback period of the developed installation is 1.5 -2 years.

\section{Conclusions}

Compared to the existing technology of drying chicken manure, when the process takes place in a drum dryer, it was possible to reduce the dimensions of the dryer by 2-3 times with the same productivity, which saved capital costs for plant design and shop construction.

This technology allowed to organize a smooth production process with maximum intensification of the drying process and automation of technological processes with the minimum possible manual labor. The initial temperature of the coolant was $600-800^{\circ} \mathrm{C}$. The calculation of specific energy consumption when drying per unit of production showed that the average heat consumption was $3500 \mathrm{~kJ} / \mathrm{kg}$ of evaporated moisture, which is on average $20-30 \%$ lower than that of drum dryers.

\section{References}

1. Lykov, A. V. (1968). Teoriya sushki [Drying theory]. Moscow: «Gos·energoizdat» (in Russian).

2. Kremnev, O. A., Borovskiy, V. R., Dolinskiy, A. A. (1963). Skorostnaya sushka [High-speed drying]. Kyiv: «Gostekhizdat USSR» (in Russian).

3. Sazhin B. S. (1984). Osnovy tekhniki sushki [Basics of drying techniques]. Moscow: «Khimiya» (in Russian).

4. Yermolenko V. O. (2002). Biolohichno aktyvni dobryva [Biologically active fertilizers]. Kyiv: NVTs ST «Vybir» (in Ukrainian).

5. Lyashenko A. V., Protsyshin B. N., Gordiyenko P. V., Fishchuk N. U. (2008). Intensifikatsiya protsessa teplomasso-obmena pri sushke termolabil'nykh pastoobraznykh materialov [Intensification of the heat and mass transfer process during drying of thermolabile paste-like materials]. Promyshlennaya teplotekhnika. $1.46-49$ (in Russian).

6. Lyashenko A. V. (2015). Analiz sposobiv intensyfikatsiyi teplomasoobminu v protsesi sushinnya ta osoblyvosti znevodnennya termolabil'nykh orhanichnykh materialiv [Analysis of methods of intensification of heat and mass transfer in the drying process and features of dehydration of thermolabile organic materials]. Tekhnologicheskiy audit i rezervy proizvodstva. 4/4 (24). 16 - 19 (in Ukrainian). 


\title{
ІНТЕНСИФІКАЦІЯ ТЕПЛОМАСООБМІНУ ТА ОСОБЛИВОСТІ ЗНЕВОДНЕННЯ ТЕРМОЛАБІЛЬНИХ ОРГАНІЧНИХ МАТЕРІАЛІВ
}

\author{
Ляшенко А. В., канд. техн. наук, с. н. с. \\ Інститут технічної теплофізики Національної академії наук України, м. Київ
}

Украӥна має високий рівень розвитку промисловості, сільського господарства та споживання. Внаслідок неповного використання видобутих речовин та продуктів їх переробки в природне середовище повертається значна кількість відходів, які забруднюють трунти, водні об'єкти, повітря. Звалища займають великі площі, надовго земля під ними виведена з виробництва, вони забруднюють природне середовище. Основні причини утворення відходів: недолік ефективних технологічних процесів та потужностей переробки залишкових продуктів, просторова та хронологічна розірваність прочесів утворення відходів та їх використання, відсутність достатнього ринку збуту.

3 усіх видів органічних відходів в Украӥні одне з головних місиь належить курячому посліду. Свіжий послід дуже небезпечна речовина, щзо окислює трунт, негативно впливає на мікроорганізми та біогумус порушує екосистеми. Необхідна певна підготовка або високотехнологічна переробка свіжого курячого посліду, як нативного так $і$ з підстілкою. Після якісної обробки курячий послід представляє собою високоякісне добриво, з високим вмістом хімічних елементів (N, $P, K)$, з макро- та мікроелементами та іншими компонентами, щзо необхідні для збільшення родючості різних рослин. Дає можливість зменшення внесення хімічних добрив.

Для знезараження посліду широко застосовують термічну сушку при $t=600-800{ }^{\circ} \mathrm{C}$. Такий сухий продукт добре зберігається, легко транспортується, але при використанні традиційних сущильних комплексів на його обробку витрачається велика кількість теплової енергії.

На сьогодні постійно створюються та пропонуються нові сучасні технологї переробки курячого послidy.

В ІТТФ НАН України також багато років проводяться дослідження зі створення сучасних технологій та обладнання по переробиі органічних відходів.

В статті представлений аналіз традииійних способів інтенсифікації процесів тепломасообміну при сушінні матеріалів. Автором показана практична реалізація та перспективність установок, щзо використовують спосіб сумісного сушіння та диспергування в одному об'ємі за допомоги механічного ротору при інтенсифікачї̈ процесу сушки високовологих термолабільних матеріалів.

Ключові слова: біомаса, енергоефективність, ресурсозбереження, технологія, обладнання.

\section{Список використаної літератури}

1. Лыков А. В. Теория сушки. М.: «Госэнергоиздат», 1968. 472 с.

2. Кремнев О. А., Боровский В. Р., Долинский А. А.. Скоростная сушка. К.: «Гостехиздат УССР», 1963. $382 \mathrm{c}$.

3. Сажин Б. С. Основы техники сушки. М.: «Химия», 1984. 320 с.

4. Срмоленко В. О. Біологічно активні добрива. К.: НВЦ СТ «Вибір», 2002. 151 с.

5. Ляшенко А. В., Процышин Б. Н., Гордиенко П. В., Фищук Н. У. Интенсификация процесса тепломассообмена при сушке термолабильных пастообразных материалов. Промышленная теплотехніка. 2008. №1. С. $46-49$.

6. Ляшенко А. В. Аналіз способів інтенсифікації тепломасообміну в процесі сушіння та особливості зневоднення термолабільних органічних матеріалів Технологический аудит и резервы производства. 2015. № 4/4 (24). C. 16 - 19 .

Отримано в редакцію 21.03.2021

Прийнято до друку 23.06.2021
Received 21.03.2021

Approved 23.06.2021 